\title{
NEW ZEALAND GLACIATIONS AND THE DURATION OF THE PLEISTOCENE *
}

\author{
By Maxwell Gage \\ (Department of Geology, University of Canterbury, Christchurch, New Zealand)
}

\begin{abstract}
Recent work has resulted in recognition of an additional glaciation preceding the Waimaunga Glaciation in the late Pleistocene. This followed the mid-Pleistocene climax of earth movements responsible for most of the present mountainous relief of New Zealand, but only after an interval of time long enough for the construction and subsequent deep dissection of Banks Peninsula shield volcano. It is inferred from this and other geological evidence that the earliest late Pleistocene glaciation was separated from the early Pleistocene Ross Glaciation by several hundred thousand years, and that the Pleistocene Period altogether covers at least one million years.
\end{abstract}

Résumé. De récentes recherches ont montré qu'une glaciation additionnelle a précédé celle de Waimaunga à la fin du Pleistocéne. Elle suivait le maximum des mouvements de l'écorce terrestre du millieu du Pleistocène ayant donné naissance à l'ensemble du relief montagneux de la Nouvelle Zélande, mais sculement après un intervalle de temps assez long pour la construction et la profonde dissection ultérieure du volcan de la Péninsule de Banks. On en déduit avec d'autres évidences géologiques que cette glaciation additionnelle était séparée de la Glaciation de Ross du début du Pleistocène par un intervalle de plusieurs centaines de milliers d'années, et qu'ainsi l'époque Pleistocène couvre une période d'au moins un million d'années.

ZuSAMmenfassung. Neuere Untersuchungen haben eine weitere Vergletscherungsphase erkennen lassen, die der Wairnaunga-Eiszeit im späten Pleistozän vorausging. Sie folgte auf den Höhepunkt jener tektonischen Bewegungen im mittleren Pleistozän, von denen der Grossteil des gegenwärtigen Gebirgsreliefs in NeuSeeland gebildet wurde; doch genügte der dazwischenliegende Zeitraum für den Aufbau und die anschliessende tiefe Zerschneidung des Schild-Vulkanes der Banks-Halbinsel. Hieraus und aus anderen geologischen Tatsachen geht hervor, dass zwischen der frühesten Vereisung im Spät-Pleistozän und der Ross-Eiszeit im Früh-Pleistozän einige hunderttausend Jahre lagen und dass das gesamte Pleistozän sich über minedestens I Million Jahre erstreckte.

\section{Glacial Sequence and Correlations}

Since formal names were introduced for Pleistocene glaciations in New Zealand ${ }^{\mathbf{I}}$ further work has shown that the Waimaunga Glaciation was preceded by a still earlier glaciation in the late Pleistocene for which the name Porika is proposed. ${ }^{2}$ The deposits which formed the basis for a supposed early Otira ice advance are now referred to the Waimaunga Glaciation. The succession as modified is:

Late
Pleistocene $\left\{\begin{array}{c}\begin{array}{c}\text { Otira Glaciation (3 advances given local names) } \\ \text { Interglacial } \\ \text { Waimaunga Graciation (now includes Hohonu advance in north Westland and } \\ \text { Woodstock advance in Canterbury) }\end{array} \\ \text { Interglacial } \\ \text { PORIKA Glaciation (based on deposits in Nelson; correlated with Avoca Glaciation } \\ \text { in Canterbury) }\end{array}\right.$

(Long mid-Pleistocene interval)

\begin{abstract}
Early
Pleistocene Ross Glaciation
\end{abstract}

A late Otira advance occurred in Otago somewhat earlier than 15,000 yr. ago ${ }^{3}$ and a mid-Otira one in Westland about 22,300 yr. ago. ${ }^{4}$ Early Otira outwash in Canterbury rests upon peat more than $45,000 \mathrm{yr}$. old which was formed after dissection and deep rather than intense weathering of Woodstock outwash. 5 These ${ }^{14} \mathrm{C}$ ages indicate that the Otira Glaciation as a whole was contemporary with the Würm and Weichsel Glaciations. The northern hemisphere correlations of earlier events in the late Pleistocene are less certain, being based

* Substance of a lecture given to the British Glaciological Society at Birmingham on 19 October 1960. 
mainly on subjective comparisons, but if the great Pleistocene climatic oscillations occurred synchronously in opposite polar hemispheres-an hypothesis which cannot be discussed here, but which the writer considers to be well supported-then one would expect to find evidence in New Zealand for events comparable with the Riss and Mindel Glaciations. Most probably these were the Waimaunga and Porika Glaciations respectively, because differential amounts of interglacial erosion and depths of weathering show that the post-Avoca interval in Canterbury was much longer than the post-Woodstock interval, in the same way as the Mindel-Riss interval appears to have exceeded the Riss-Würm.

The tectonic mountain ranges of New Zealand owe their elevation to the "Kaikoura" movements which began in late Tertiary times and culminated in the mid-Pleistocene. As the Porika Glaciation did not occur until considerably later than the climax of these crustal movements, the last three glaciations may be assigned to the late Pleistocene. On the other hand, the Ross Glaciation preceded the orogenic climax. Its early Pleistocene age, based upon stratigraphic evidence, ${ }^{6}$ suggests that it may have coincided with the early cold episode marked by the Praetiglian in Holland.

\section{Mid-Pleistocene Hiatus}

A large part of the present land area of New Zealand emerged from the ocean during the Kaikoura movements, and the uplift was such that clevations of up to $12,000 \mathrm{ft}$. $\left(3,65^{8} \mathrm{~m}\right.$.) still survive. Stratigraphically, the event is expressed by almost ubiquitous unconformity between Pliocene-early Pleistocene (Wanganui) and late Pleistocene (Hawera) series. ${ }^{7}$ Even within the region where sedimentation was the most nearly continuous it is necessary to postulate local uplift sufficient to explain a deficiency of $4,000 \mathrm{ft}$. (1,2 I9 m.) of Wanganui strata. ${ }^{8}$ The Ross glacial beds form part of a thick sequence of beds that had been deposited before the climax of the movements and later differentially uplifted, folded and eroded, whereas the Porika Glaciation did not occur until after erosion had carved the main outlines of the present landscape from the elevated crustal segments. Its setting is essentially modern.

Geological work of a far greater magnitude was performed during the lapse of time between the Ross and Porika Glaciations than during either of the two late Pleistocene interglacial periods. The major item was the orogenic climax, but there is evidence of other important changes, of which one example will be given. After vigorous crustal movements had ceased, intermittent eruptions of mainly basaltic lava from two centres built the Banks Peninsula shield volcano. The eroded remnants of the double volcano still rise to over 3 , ooo ft. $\left(914 \mathrm{~m}\right.$.), and occupy an elliptical area of $3^{1}$ miles by 18 miles $\left(5^{\circ} \mathrm{km}\right.$. by $29 \mathrm{~km}$.) at sea-level. These dimensions are considerably less than the original height and the full extent of the base which is submerged beneath the sea and beneath the Canterbury Plain on the landward side. Although the volcano stands alongside the south-westward continuation of the Kermadec Trough, ${ }^{9}$ the lava sheets composing the dome are disturbed only by minor radial faults of volcanic rather than tectonic origin. In contrast, the surrounding region north-west of the trough is characterized by young tectonic ranges, the nearest of which is less than 40 miles $(64 \mathrm{~km}$.) from the volcano, and involves early Pleistocene strata in a complex anticline with dips as steep as $65^{\circ}$ in places. If the shield volcano had been even partially built before the movements ceased, deformation of at least the lower portions should be observed, for dissection is far advanced. Broad erosion calderas occupy the sites of the two main eruptive centres, and the flanks have been breached so as to expose the basement rocks and to allow the sea to invade both calderas. Both inner and outer slopes are extensively coated with loess up to at least $\mathrm{I}, 600 \mathrm{ft}$. $(488 \mathrm{~m}$.) a.s.1. and as much as $20 \mathrm{ft} .(6 \cdot 1 \mathrm{~m}$.) thick in places. Such a thickness is not found farther inland on surfaces younger than the Avoca ice advances and, moreover, as the loess is free from airborne volcanic ash, one can infer that volcanic action had ceased before the Porika Glaciation. The Ross-Porika time- 
interval must therefore contain, successively, the culmination of the Kaikoura movements, the building of Banks Peninsula shield volcano, and its deep dissection. It hardly can have been less than the time that has elapsed since the Porika Glaciation, and quite credibly it may have been twice as much.

\section{Estimations of Pleistocene Time}

Modern estimations of the duration of Pleistocene time are based upon various methods, involving different proportions of extrapolation relative to direct measurement, and in combination with different methods for detecting climatic variations. The methods themselves will not be discussed here, but the results of some modern estimations will be considered with regard to whether the climatic incidents identified and dated appear to be appropriately spaced when compared with the geological record. It may be remarked that climatic changes have been found to provide convenient reference points on Pleistocene absolute time scales, and even by those authors who do not consider climate to be the best criterion for the geological definition and sub-division of the Pleistocene Period.

Zeuner ${ }^{\text {II }}$ continues to support a chronology based upon the Milankovitch theory of radiation minima. The Pleistocene is considered to begin with the "Early" or Günz Glaciation, dated at about 600,000 yr. ago, but the possibility of pre-Günz glaciations is not denied. Extreme extrapolation of the radiation curves suggests that cold periods might have occurred around 830,000 and 920,000 yr. ago, but these dates are beyond the reliable range of the method. If one accepts the estimate of $600,000 \mathrm{yr}$. for the whole Pleistocene, and identifies Ross and Porika Glaciations respectively with Early and Antepenultimate on Zeuner's scale, the interval between them is only about $100,000 \mathrm{yr}$., which seems quite inadequate. Alternatively, one may speculate that the Porika Glaciation, which was decidedly a double event in Canterbury at least, might represent both Early and Antepenultimate, and that one or both of the earlier radiation minima is perhaps marked by the Ross Glaciation.

Emiliani's ${ }^{\mathrm{I} 2}$ investigation of ocean floor sediment cores indicated cool periods at $175,000-$ 200,000 and I03,000-I25,000 yr. ago, which were correlated respectively with Mindel and Riss, while the beginning of the Pleistocene was placed at 600,000 yr. ago. Flint ${ }^{\mathrm{I}} 3$ reported Emiliani's findings as being probably of the correct order, but he thought it premature to tabulate an absolute chronology for the whole Pleistocene. Emiliani's results would make the Mindel-Riss interval little greater than the lapse of time since the beginning of the Würm Glaciation, but these proportions do not match with the contrast between great erosion and deep weathering in the Porika-Waimaunga interval on one hand, and minor differences in the weathering of early and late Otira deposits on the other.

The chronology by Arrhenius, ${ }^{14}$ also based upon oceanic sedimentation rates, suggests that a long period of Tertiary warmth ended with a double cool oscillation at $940,000-990,000$ yr. ago which invites correlation with the Ross Glaciation. A cooling at 310,000-350,000 yr. ago is tentatively correlated with Mindel, and might also be correlated with Porika, leaving an adequate span of $600,000 \mathrm{yr}$. for the Ross-Porika interval. On the other hand the MindelRiss interval is made shorter than the Riss-Würm, whereas the geological evidence would suggest it was the longer of the two interglacial periods. Broecker, Turekian and Heezen ${ }^{15}$ critically examined the data from which sedimentation rates have been derived by various authors and, while their findings are in reasonable agreement with Arrhenius's datings of the Riss and Würm, they advise great caution in extending application of the method to the early Pleistocene.

Hough's results ${ }^{\text {I6 }}$ are perhaps in a different case because ages were determined from ocean bottom cores by the radium/ionium method, which has a range of up to 300,000 yr., and involve a smaller ratio of extrapolation than other estimations depending upon ${ }^{14} \mathrm{C}$ measurements. The time scale proposed is considerably longer than the other estimates 
considered here. A cool period that ended between 680,000 and 750,000 yr. ago is identified with the Kansan, the most probable American correlation of the Porika, so that if the scale is expanded proportionately, the full Pleistocene span would amount to $1 \cdot 5-2 \cdot 0$ million years. Kulp ${ }^{17}$ adopted an estimate of 0.6 million years for the interval since the beginning of The Ice Age, and an arbitrary figure of $I \cdot 0$ million for the whole Pleistocene. Holmes ${ }^{{ }^{8}}$ gives I 'o million years as a "round figure" for the Pleistocene, although he noted that the Bishop Tuff in California, dated by the potassium-argon method at $\mathrm{I} \cdot \mathrm{o}$ million years, rests upon an older moraine.

\section{Conclusions}

There appear to be preferences for estimates of about 0.6 million and about $\mathrm{I} \cdot \mathrm{O}$ million years for the duration of the Pleistocene. The Pleistocene geological history of New Zealand appears to demand a duration of at least one million years, and it does not fit well with the space datings of major climatic conditions according to detailed chronologies which have been published.

MS. received, I November 1960

\section{REFERENGES}

I. Gage, M., and Suggate, R. P. Glacial chronology of the New Zealand Pleistocene. Bulletin of the Geological Society of America, Vol. 69, 1958 , p. 593.

2. Suggate, R. P. Personal communication. Reasons for the proposed changes will be presented in another paper now in preparation.

3. According to internal correlations favoured by Suggate and Gage, and ${ }^{14} \mathrm{C}$ age determination published by I. G. McKellar. (Pleistocene deposits of the Upper Clutha Valley, Otago, New Zealand. Nere Zealand Journal of Geology and Geophysics, Vol. 3, No. 3, 1960, p. 443, 458).

4. Gage, M., and Suggate, R. P. op. cit., p. 596.

5. Gage, M. Late Pleistocene glaciations of the Waimakariri Valley, Canterbury, New Zealand. New Zealand Journal of Geology and Geophysics, Vol. I, No. I, 1958, p. I40. [The Woodstock Advance is not referred to the Waimaunga Glaciation.]

6. Gage, M. On the definition, date and character of the Ross Glaciation, Early Pleistocene, New Zealand. Transactions of the Royal Society of New Zealand. [In press.]

7. Fleming, C. A. The geology of Wanganui Subdivision. New Zealand Geological Survey Bulletin, New Scries, No. 52, 1955, p. 20, 246.-Hawera Series. (In Lexique stratigraphique internationale, Pt. VI, Océanie, Fasc. 4 , New Zealand, 1959, p. 126-27.)

8. Morgan, P. G. Notes on the geology of the Patea district. Transactions of the New Zealand Institule, Vol. 53, I 921 , p. $58-64$.

9. Hatherton, T. Gravity profiles across the Canterbury Plains. New Zealand Journal of Science and Technology, Sect. B, Vol. 34, No. I, I953, p. I3-20.

Io. Gregg, D. R. Stratigraphy of the Lower Waipara Gorge, North Canterbury. Newe Zealand Journal of Geology and Geophysics, Vol. 2, No. 3, 1959, p. 503.

I1. Zeuner, F. E. The Pleistocene period. [Second edition.] London, Hutchinson, 1959, p. 185, 218,2 1 9.

12. Emiliani, C. Pleistocene tempcratures. Journal of Geology, Vol. 63, No. 6, r 955, p. 565 .

13. Flint, R. F. Glacial and Pleistocene geology. New York, John Wiley \& Sons, [r957], p. 292, 301, 442.

14. Arrhenius, G. Sediment cores from the Eastern Pacific. Swedish Deep Sea Expedition 1947-48, Reports. Vol. 5, Fasc. I, 1952, p. 198-200.

I5. Broecker, W. S., and others. The relation of dcep-sea sedimentation rates to variations in climate, [by] W. S. Broecker, K. K. Turekian and B. C. Heezen. American Journal of Science, Vol. 256, i958, p. 503-г 7.

I6. Hough, J. L. Pleistocene climatic record in a Pacific Ocean core sample. Journal of Geology, Vol. 6r, No. 3, I953, p. 252-62.

17. Kulp, J. L. The geological time scale. International Geological Congress. Report of twenty-first session, Norden, 1960 , Part III, 1960, p. 22.

18. Holmes, A. A revised geological time scale. Transactions of the Edinburgh Geological Society, Vol. 17, Pt. 3, I 960 , p. 203. 